\title{
Response of bio-regulators to morphology and yield of clusterbean [Cyamopsis tetragonoloba (L.) Taub.] under different sowing environments
}

\author{
Hemraj Meena, Ram Swaroop Meena*, Bhalendra Singh Rajput and Sandeep Kumar \\ Department of Agronomy Institute of Agricultural Sciences, Banaras Hindu University, Varanasi -221 005 (UP), INDIA \\ *Corresponding author. E-mail: rsmeenaagro@gmail.com
}

Received: August 8, 2015; Revised received: February 23, 2016; Accepted: May 5, 2016

\begin{abstract}
An experiment was conducted during kharif season of 2014, aims of the experiment were to investigate suitable sowing environment and bio-regulator and its effect on clusterbean (Cyamopsis tetragonoloba (L.) Taub.), experimental treatments were applied foliar spray of thiourea $(500,1000 \mathrm{ppm})$ and salicylic acid $(50,100 \mathrm{ppm})$ at 45 and 60 days after sowing under normal (15 July) and late (30 July) sowing environments. Normal sowing performed well as compared to late sowing, in respect to all morphology and yield parameters. Amongst foliar spray, significantly higher plant height $(100.17 \mathrm{~cm})$, number of branches per plant $(7.99)$, leaf area index $(4.85)$, seed yield $(9.19 \mathrm{q} / \mathrm{ha})$ and harvest index (29.39) were recorded in foliar spray of thiourea $500 \mathrm{ppm}$ as compared to all other bio -regulators spray level. Similarly, salicylic acid 100 ppm found statistically at par with thiourea 500 ppm foliar spray at 45 and 60 DAS. Impacts of climate change have significant reflections on clusterbean productivity. Sowing dates plays a vital role to determining the productivity of clusterbean with bio-regulators spray by controlling the environmental factors.
\end{abstract}

Keywords: Clusterbean, Salicylic acid, Sowing environments, Thiourea

\section{INTRODUCTION}

Clusterbean [Cyamopsis tetragonoloba (L.) Taub.] known as 'Guar', is a drought hardy crop widely grown in arid and semi-arid regions of India. Guar seed contains sufficient amount of galactomannan gum, which forms a viscous gel in cold water (Meena and Meena, 2015). Among the several factors responsible for its low productivity, proper date of sowing is one of the important practice has considered as major constraints. In rainfed agriculture, farmers have limited choice for sowing time, but in irrigated situation sowing time is one of the most important non - monetary input affecting yield of crops (Meena and Yadav, 2013). The yield and quality of clusterbean crop can be improved by use of plant growth regulators. The recent research findings indicate the use of bio-regulators for increasing productivity (Hayat and Ahmad, 2007). These bio-regulators act as chemical catalyst in the plant and improve physiology and reproductive efficiency in the plant. These bio-regulators possibly improve the sucrose transport and increase dry matter partitioning for grain production (Dadhich et al., 2015a). This paper examines the role of foliar application of bio-regulators to mitigate the environmental stress in crop production. The farmers may use the bio-regulators to mitigate the different stress like drought stress, saline stress and temperature stress etc. that come due to adverse environment.

\section{MATERIALS AND METHODS}

Experimental site: A field experiment was conducted during kharif season of 2014-15 at Agronomy farm of Rajiv Gandhi South Campus Banaras Hindu University, Barkachha, Mirzapur, Uttar Pradesh, which is situated in Vindhyan region of district Mirzapur (25 $15^{\circ}$ ' latitude, $82^{\circ} 37^{\prime}$ longitude and altitude of 147 meters above mean sea level. This region comes under agro-climatic zone III A (Semi-Arid Eastern Plain Zone) and the region is mostly rainfed. Crop sowing as agro-horti based system between row of guvava tree spacing of 7 X 7 meter, guava trees were 9 year old planted in August 2007.

Treatments detail: Experiments were carried out on clusterbean in the alleys of guava trees. The experiment was laid out in split-plot design with three replications, assigning 10 treatments combinations, consisting of two date of sowing (Normal sowing and Late sowing) in main-plots and water spray as control, foliar spray of thiourea $(500,1000 \mathrm{ppm})$ and salicylic acid (50, $100 \mathrm{ppm}$ ) in sub-plots at 45 and 60 DAS. Clusterbean cultivar RGC-936 was sown at a spacing of $30 \mathrm{~cm} \times 15$ $\mathrm{cm}$ in normal sowing and late sowing. Data on various growth and yield attributes grain and straw yields of clusterbean were calculated as per the standard procedures (Gomez and Gomez, 1984).

Physico-chemical properties of experimental soil: The soil of the experimental site was sandy loam and having $186 \mathrm{~kg} / \mathrm{ha}$ alkaline permanganate oxidizable $\mathrm{N}$ 
(Subbiah and Asija, 1956), $20.97 \mathrm{~kg} / \mathrm{ha}$ available $\mathrm{P}$ (Vanado-molybdo - phosphoric acid yellow colour method (Jackson,1973). 243.38 kg/ha, Flame photometer method (Jackson, 1973) and $0.35 \%$ organic carbon chromic acid rapid titration method (Walkey and Black, 1934). The $\mathrm{pH}$ of soil was 5.8 using Glass electrode $\mathrm{pH}$ meter (Jackson, 1973).

\section{RESULTS AND DISCUSSION}

Effect of sowing environments: The present study showed that maximum morphological parameters of clusterbean viz., height, number of branches per plant and leaf area index were observed in normal sowing than late sowing (Table 1, Fig. 1 ), primarily due to the differences in the environmental constitutions and growth habit of the crop as evidenced from the variation in crop growth parameters with sowing dates. The variable behavior of crop could be explained in sowing. Normal crop sown was exposed to longer duration for vegetative growth and perform better than late sowing, similar results were reported that on groundnut and observed maximum yield in early sowing than late sowing (Meena et al., 2015; Gouri et al., 2005). Thus, the variation in growth parameters with sowing environments, resulted yield parameters also affected with sowing (Table 2) like seed, straw, biological yields and harvest index were affected due to the variation in moisture availability vis-a-vis environmental factor like temperature, day length, relative humidity, rainfall, wind velocity and biotic and abiotic factors which have a considerable bearing on important plant functions such as photosynthesis, respiration, transpiration, nutrient and water absorption etc. These results was also in close agreement with the findings of several workers on groundnut and observed that as per growing degree days highest yield observed in early sowing than late sowing, this is due to early sowing covered more number of growing degree days than late sowing (Leong and Ong, 1983; Meena and Yadav, 2012; Meena et al., 2013; Meena et al., 2014a).

Effect of bio-regulators: Amongst foliar spray of bio-regulators, critical difference (CD) values at $p=0.05$ were used for determine the significance and observed higher plant height, number of branches per plant, leaf area index were recorded in thiourea 500 ppm as compared to all other bio-regulators spray level. Similarly, foliar spray of salicylic acid $100 \mathrm{ppm}$ found statistically at par with thiourea 500 ppm at 45 and 60 DAS. Foliar spray of thiourea and salicylic acid

Table 1. Effect of sowing environments and bio-regulators on growth parameters of clusterbean under guava based agri-horti system.

\begin{tabular}{|c|c|c|c|c|c|c|}
\hline \multirow[t]{2}{*}{ Treatment } & \multicolumn{3}{|c|}{ Plant height (cm) } & \multicolumn{3}{|c|}{ Number of branches/plant } \\
\hline & 30 DAS & 60 DAS & At harvest & 45 DAS & $60 \mathrm{DAS}$ & At harvest \\
\hline \multicolumn{7}{|l|}{ Sowing date } \\
\hline Normal Sowing & 21.75 & 86.39 & 99.39 & 4.46 & 6.04 & 7.92 \\
\hline Late sowing & 20.69 & 76.07 & 89.07 & 3.39 & 4.89 & 6.97 \\
\hline $\mathrm{SEm} \pm$ & 0.09 & 1.19 & 1.19 & 0.12 & 0.11 & 0.11 \\
\hline C.D. $(p=0.05)$ & 0.57 & 7.25 & 7.25 & 0.76 & 0.67 & 0.67 \\
\hline \multicolumn{7}{|c|}{ Foliar spray of bio-regulators } \\
\hline Water spray & 21.22 & 71.17 & 84.17 & 3.97 & 4.60 & 6.52 \\
\hline Thiourea $1000 \mathrm{ppm}$ & 21.51 & 87.88 & 100.88 & 3.88 & 6.13 & 8.06 \\
\hline Thiourea 500 ppm & 21.37 & 87.17 & 100.17 & 3.90 & 6.07 & 7.99 \\
\hline Salicylic acid 100 ppm & 20.93 & 84.70 & 97.70 & 3.80 & 5.84 & 7.76 \\
\hline Salicylic acid 50 ppm & 21.06 & 75.22 & 88.22 & 4.10 & 4.69 & 6.89 \\
\hline $\mathrm{SEm} \pm$ & NS & 1.27 & 1.27 & 0.22 & 0.12 & 0.12 \\
\hline C.D. $(p=0.05)$ & NS & 3.81 & 3.81 & NS & 0.35 & 0.35 \\
\hline
\end{tabular}

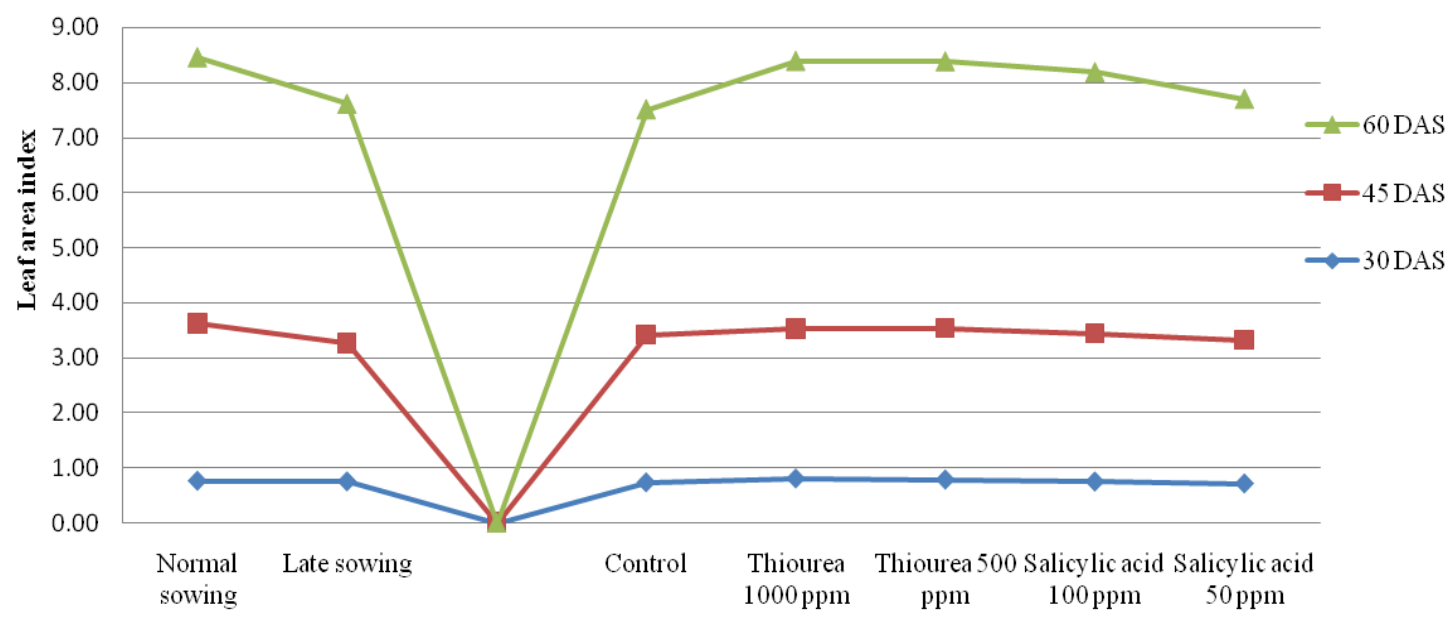

Fig. 1. Effect of sowing environments and bio-regulators on leaf area index of clusterbean under guava based agri-horti system. 
Table 2. Effect of sowing environments and bio-regulators on yield parameters of clusterbean under guava based agrihorti system.

\begin{tabular}{lllll}
\hline Treatment & $\begin{array}{l}\text { Seed yield } \\
(\mathbf{q} / \mathbf{h a})\end{array}$ & $\begin{array}{l}\text { Straw yield } \\
(\mathbf{q} / \mathbf{h a})\end{array}$ & $\begin{array}{l}\text { Biological yield } \\
(\mathbf{q} / \mathbf{h a})\end{array}$ & Harvest index (\%) \\
\hline Sowing date & & & & \\
\hline Normal Sowing & 9.12 & 24.01 & 33.11 & 29.16 \\
Late sowing & 8.17 & 21.48 & 29.65 & 26.02 \\
SEm \pm & 0.11 & 0.31 & 1.58 & 0.32 \\
C.D. $(p=0.05)$ & 0.67 & 1.87 & 9.64 & 1.93 \\
\hline Foliar spray of bio-regulators & & & & \\
\hline Water spray & 7.72 & 20.39 & 28.06 & 29.69 \\
Thiourea 1000 ppm & 9.26 & 24.27 & 33.53 & 29.39 \\
Thiourea 500 ppm & 9.19 & 24.26 & 33.45 & 28.39 \\
Salicylic acid 100 ppm & 8.96 & 23.66 & 32.63 & 25.88 \\
Salicylic acid 50 ppm & 8.09 & 21.14 & 29.23 & 0.35 \\
SEm \pm & 0.12 & 0.30 & 2.12 & 1.05 \\
C.D. $(p=0.05)$ & 0.35 & 0.89 & 6.36 &
\end{tabular}

applied at initiation of branches and flowering stages brought about significant improvement in clusterbean morphological parameters (Table 1, Fig.1.). It may also be noted that growth parameters increased due to the effects of thiourea and salicylic acid spray. Higher crop morphology is the result of photosynthesis, which mainly depends upon the utilization of solar energy through crop canopy along with other essentials. Similar findings were reported by various researchers (Dadhich et al., 2015a; Dadhich and Meena, 2014; Meena et al., 2014b) on bio-regulators spray and observed on significant crop growth with thiourea and salicylic acid might be attributed due to considerable increase in number of branches and effective utilization of nutrient, moisture and light .

Thiourea 500 ppm (100 ppm) and salicylic acid 100 ppm foliar spray were similarly improved yield parameter viz, seed, straw, biological yields and harvest index (Table 2). This may be due to metabolic reaction in the plant systems both water as well as environmental stress conditions. The increase in the yield recorded in the present investigation could be a reflection of the effect of bio-regulators on growth and development; it might be due to marked increase in the number of branches per plant, which gave a chance to the plant to carry more flowers, pods and hence more seeds. Similarly, marked increase in the photosynthetic pigments content which could lead to increase in photosynthesis, resulting in greater transfer of assimilates to the seeds and causing increase in their weight. The beneficial results were also reported on Indian mustard with spray of thiourea and salicylic acid by several workers viz. Atta-aly et al. (2000), Meena et al. (2015); Dadhich et al. (2015b).

\section{Conclusion}

The present study demonstrated that normal sowing was performed better than late sowing, and amongst bio-regulators spray at 45 and 60 DAS observed that thiourea 500 ppm improved plant height $(100.17 \mathrm{~cm})$, number of branches per plant (7.99), leaf area index (4.85), seed yield $(9.19 \mathrm{q} / \mathrm{ha})$ and harvest index (29.39). Similarly, foliar spray of $100 \mathrm{ppm}$ salicylic acid improved plant height, number of branches per plant, leaf area index, yields and harvest index. Bio-regulators are chemicals that affect the expression of biological responses in plant tissues. Their use is a unique new approach of manipulating plant biochemistry for enhancing productivity and quality. They act in low concentration without any biocidal or nutritive action. Applications of bio-regulators are reported to reduce environmental stress under current climate in plants and improved economical yield of clusterbean.

\section{REFERENCES}

Atta-aly, M.A., Riad, G.S., Lacheene, Z. El-S and Beltagy, A.S. (2000). Early application of ethrel extends tomato fruit cell division and increases fruit size and yield with ripening delay. Journal of Plant Growth Regulator, 18:15-25.

Dadhich, R.K. and Meena, R.S. (2014). Performance of Indian mustard (Brassica juncea L.) in response to foliar spray of thiourea and thioglycollic acid under different irrigation levels. Indian Journal of Ecology, 41 (2): $376-378$.

Dadhich, R.K., Reager, M.L., Kansoti, B.C. and Meena, R.S. (2014). Efficacy of growth substances on mustard (Brassica juncea L.) under hyper arid environmental condition of Rajasthan. The Ecoscan., 8 (3 \& 4): 269272.

Dadhich, R.K., Meena, R.S., Reager, M.L. and Kansotia, B.C. (2015a). Response of bio-regulators to yield and quality of Indian mustard (Brassica juncea L. Czernj. and Cosson) under different irrigation environments. Journal of Applied and Natural Science. 7 (1) : 52 - 57.

Dadhich, R.K., Reager, M.L., Meena, R.S. and Kansotia. B.C. (2015b). Effect of foliar spray of thiourea and thioglycollic acid on mustard (Brassica juncea L.). Bioinfolet. 12(1A):10-13.

Gomez, K.A. and Gomaz, A.A. (1984). Statistical Procedures for Agricultural Research. John Wiley and Sons, Singapore.

Gouri, V., Reddy, R., Narayansimha, S.B.S., Rao, Y.A. (2005). Thermal requirement of rabi groundnut in Southern Telangana Zone of Andhra Pradesh. Journal of Agrometeorology. 7(1):09-94.

Hayat, S. and Ahmad, A. (2007). Salicylic Acid: A Plant Hormone. Springer Publishers, Dordrecht, the Netherlands Pp 1-371. 
Jackson, M.L. (1973). Soil Chemical Analysis. Prentice Hall of Inc. Engle Chiffs. New Jersey.

Leong, S.K., Ong, C.K. (1983). The influence of temperature and soil water deficit on the development and morphology of peanuts (Arachis hypogaea L.). Journal of Experimental Biotechnology, 34: 1551-1561.

Meena, R.S. and Yadav, R.S. (2013). Groundnut yields as influenced by heat unit efficiency, fertility levels and varieties under different growing environment in hyper arid of Rajasthan. Indian Journal of Ecology, 40(1):110 $-114$.

Meena, R.S., and Meena, H.R. (2015). Role of Bio-regulators in Clusterbean (Cyamopsis tetragonoloba L.) productivity. Annals of Agri-Bio Research, 20 (1) : 37-39.

Meena, R.S., Yadav, R.S. and Meena, V.S. (2013). Heat Unit Efficiency of Groundnut Varieties in Scattered Planting with Various Fertility Levels. The Bioscan, 8 (4):1189-1192.

Meena, R.S., Yadav, R.S., Reager, M.L., De, N., Meena, V.S., Verma, J.P., Verma, S.K. and Kansotia, B.C. (2015a). Temperature use efficiency and yield of groundnut varieties in response to sowing dates and fertility levels in western dry zone of India. American
Journal of Experimental Agriculture, 7(3): 170-177.

Meena, R.S. and Yadav, R.S. (2014). Phenological performance of groundnut varieties under sowing environments in hyper arid zone of Rajasthan, India. Journal of Applied and Natural Science, 6 (2): 344-348.

Meena, R.S., Meena V.S., Meena, S.K., and Verma, J.P. (2015b). Towards the plant stress mitigate the agricultural productivity: a book review. Journal of Cleaner Production, 102:552-553.

Meena, V.K., Kaushik, M.K. and Meena, R.S. (2014a). Response of Clusterbean [Cyamopsis tetragonoloba (L.)] to growth substances in sub-tropical climate of Rajasthan. Indian Journal of Ecology. 41(1): 190-191.

Meena, V.K., Kaushik, M.K., Meena, RS., Meena, V.S., and Meena, B.P. (2014b). Effect of growth regulators on clusterbean [Cyamopsis tetragonoloba (L.)] Growth under Aravali hills environment in Rajasthan. The Bioscan, 9(2): 547-550.

Subbiah, B.V., and Asija, G.L. (1956). A rapid procedure for the determination of available nitrogen in soils. Current Sciences, 25: 259-260.

Walkey, A., and Black, I.A. (1947). Rapid titration method for organic carbon of soils. Soil Science, 37:29-32. 